\section{New Questions}

Thinking of cross-border higher education as a private enterprise in the traditional sense oversimplifies the true nature of the organizations. Even though they operate in the private sector and are regulated as private entities, as extensions of a public government, many cross-border endeavors raise new questions about the role and operation of these institutions. Are such institutions truly independent institutions? To what extent does a home government's political agenda affect operations of the cross-border activity? As research continues in this arena, such questions need to be further investigated in order to provide a more robust understanding of this phenomenon.

\section{Jamaica's Development Goals and GATS Commitment}

\section{TERENCE Frater}

Terence Frater holds a PhD in comparative education from the University of Toronto. E-mail: tfrater@oise.utoronto.ca.

J amaica, a small developing Caribbean nation that ranks among the most indebted countries worldwide is plagued by high rates of violent crime, unemployment of over I3 percent, migration of its graduates estimated at over 70 percent, and one of the lowest per capita GDP in the region. It is felt that higher education - a sector particularly linked to knowledge creation, social mobility, and economic growth — can play a pivotal role in the country meeting its development needs and overcoming its social and economic deficits. This is the sector currently most associated with trade liberalization and experiencing the greatest level of expansion across national borders. Jamaican higher education originated in the I83os with the creation of teachers colleges and theological colleges and has since expanded into a diverse and complex system of public and private universities, colleges, and other institutions, which includes a growing number of cross-border providers from the United States, the United Kingdom, and Canada.

The urgency to create more effective policy mechanisms for the sector and to become more competitive in navigating the complexities of emergent global accords became more acute for Jamaica with the changed geopolitical dynamics at the end of the cold war and the growing endorsement of free trade. However, the creation of the General Agreement on Trade in Services (GATS) - the services agreement of the World Trade Organization (WTO) - together with liberalization trends in education raised specific concerns that developing countries like Jamaica would be unable to implement higher education policies related to their development goals.

\section{Jamaica's GATS COMmitment in Higher Education}

In I994 Jamaica was among a number of developing countries to include higher education in its GATS Schedule of Commitments. In doing so, it assumed legally binding obligations in the sector and subjected policy initiatives to the governance of the WTO. Interviews with Jamaican politicians, in both government and opposition, and senior education and trade policymakers revealed negotiators were able, without consultation, to set a higher education agenda based on their own experience and beliefs dealing with other sectors of the economy. No process existed at the time to trigger dialogue between negotiators and education stakeholders. The GATS commitment appeared largely affected by a culture of liberalization and free trade, together with a sense of the need to expand access to higher education.

Jamaica is not unique in this regard. Around the globe, education stakeholders reacted rather late to trade liberalization trends occurring in the sector. They considered it a "public good," isolated from the marketplace. Consequently, trade negotiators were instrumental in crafting GATS commitments based on their own rationale- that is, contributing to economic growth, expanding access, and enhancing quality.

Jamaican trade policymakers suggested that GATS presented opportunities to position the country's higher education sector as an export industry. They proposed marketing the country's internationally recognized English-language higher education system to Latin American students, similar to how Australia and New Zealand marketed their system to Asian

\section{Jamaican trade policymakers suggested that GATS presented opportunities to position the country's higher education sector as an export industry.}

students. These policymakers also regarded the emigration of Jamaican graduates as contributing positively to the economy in the form of remittances. They were less concerned about potential threats from liberalization and the WTO.

Education stakeholders, however, were ignorant of the initiative until it surfaced in public debate almost io years after coming into force. They regarded the GATS commitment as a threat to both equity in higher education and introducing safeguards to maintain the quality of the system. Additionally, they were greatly concerned about the presence of foreign providers and the potential of foreign credentials to exacerbate the migration problem. Nonetheless, the potential of the commitment to expand access to higher education was embraced.

Politicians in both government and opposition were also caught by surprise and questioned the capacity of the negotiators to have crafted without dialogue a higher education com- 
mitment based on a coherent education or development strategy. They were concerned about Jamaica's freedom to regulate the sector to meet its development goals. Government officials spoke of the "knowledge divide" separating rich and poor countries and recounted the daunting task, when attending international forums, of negotiating with countries vastly superior in human capital and financial resources. Still, neither politicians nor trade and education stakeholders suggested withdrawal of the commitment. Therefore, they called for greater dialogue to ensure Jamaica's interests could be safeguarded and the role of higher education in the development process preserved.

\section{CONCLUSION}

Jamaica now recognizes that education policy must objectively engage and balance the social and economic dimensions of knowledge creation and national development. This process requires dialogue between stakeholders in all relevant sectors, to align the country's development strategy with models for public policy and government's role in managing the system. Policymakers admitted the absence of a coherent framework to harness the opportunities and navigate the threats posed by GATS on higher education. There was no process in existence that might have inspired and supported the type of dialogue necessary between the education sector and trade negotiators. The challenge that Jamaica now faces is how to reconcile its GATS commitment of higher education with its development goals.

\section{Transnational Education in China: Challenges, Critical Issues, and Strategies for Success}

\section{Robin Matross Helms}

Robin Matross Helms is an international education consultant in Washington, DC. E-mail: robin.m.helms@gmail.com. This article is based on a report written by the author for the Observatory on Borderless Higher Education (http://www.obhe.ac.uk/).

$\mathrm{O}$ ver the past decade, China has become an increasingly popular market for transnational education ventures. Through creating student exchanges and twinning programs, to building study centers and establishing full branch campus- es, higher education institutions and organizations worldwide have eagerly sought to capture a share of the lucrative and expanding Chinese market.

As more institutions have tried their hands in the Chinese market, however, reports are suggesting that to establish and operate a successful campus or program in China is often easier said than done. Regulatory, cultural, and logistical challenges abound-from understanding national, provincial, and local requirements, to establishing effective partnerships and building networks, to finding an appropriate campus and classroom equipment.

To gain a clearer picture of the prospects for transnational education providers in China, the pros and cons of entering the Chinese market, and the challenges involved, the Observatory on Borderless Higher Education commissioned a report on the experiences of three different institutions with successful operations in China: Missouri State University and the Stanford Center for Professional Development, based in the United States; and CIBT School of Business and Technology Corporation, based in Canada. Leaders of each institution were interviewed about key issues, critical challenges, and strategies for success.

\section{Regulatory IsSUes AND ACCREDitation}

The regulatory environment for transnational education ventures in China consists of a web of interrelated national, provincial, and local regulations and policies, which are interpreted and applied with varying degrees of consistency. The institutional leaders indicate that three regulations are most critical for foreign providers. First, all degree-granting transnational programs must operate in cooperation with a Chinese partner institution. Second, profit generation cannot be the driving objective of such ventures (the regulation itself is not entirely clear, but this appears to be the dominant interpretation). Third, transnational providers are subject to a variety of provincial and local regulations-often best handled by the Chinese partner institutions.

Chinese regulations also state that programs operating in China must be accredited by the relevant accrediting body of the parallel program on the home campus. The institutional leaders emphasized the importance of actively engaging with accrediting bodies - that is, by inviting them to visit the China operations and maintaining transparency, to ensure that the accreditation and academic reputation of the home institution are protected.

\section{Partners}

The three institutional leaders judged identifying an appropriate partner institution as an important aspect of any China venture. Key factors include the potential partner's reputation and geographic location (i.e., with sufficient demand for higher education and enough students able to pay foreign tuition rates). In addition, the management style of the partner should be an important consideration. Partners must be flexible, 